\title{
Actinomyces in Tonsillectomy Materials
}

\author{
Tonsillektomi Materyallerinde Aktinomiçes
}

Ozlem Ceren Gunizi ${ }^{1}$, Huseyin Gunizi ${ }^{2 *}$

1.Departmant of Pathology, Alanya Alaaddin Keykubat University, Faculty of Medicine, Alanya, Turkey

2.Departmant of Otolaryngology Alanya Alaaddin Keykubat University, Faculty of Medicine, Alanya, Turkey

\section{ABSTRACT}

Aim: Tonsillectomy is one of the most common surgeries in the pediatric age group. Actinomyces species are Gram-positive, non-spore-forming facultative anaerobic bacteria. Actinomycosis is a disease characterized by abscess formation, ranging from subacute to chronic infection.

Materials and methods: We studied with the tonsillectomy materials of 185 patients who underwent tonsillectomy in our clinic between January 2016 and January 2019. Results: A total of 185 patients, $98(53 \%)$ males and $87(47 \%)$ females, who underwent tonsillectomy were included in the study. The mean age was 12.6 (range, 3-56) years. A total of 64 patients showed the presence of Actinomyces.

Conclusion: Actinomyces species are bacteria found in the tonsil tissue flora that cause opportunistic infection. Tonsillar Actinomyces colonization is more common in adults and in older children.

Key words: Tonsillectomy, Histopathology, Actinomyces

\section{ÖZ}

Amaç: Tonsillektomi çocuk yaş grubunda en sık yapılan ameliyatlardan birisidir. Actinomiçes türleri Gram-pozitif, spor oluşturmayan fakültatif anaerobik bakterilerdir. Aktinomikoz, subakuttan kronik enfeksiyona kadar apse oluşumu ile karakterize bir hastalıktır.

Yöntem: Ocak 2016 - Ocak 2019 tarihleri arasında Alanya Alaaddin Keykubat Üniversitesi Eğitim ve Araştırma Hastanesinde tonsillektomi uygulanan 185 hastanın tonsillektomi materyalleri ile çalıştık.

Bulgular: Tonsillektomi yapılan 98 (\% 53) erkek ve 87 (\% 47) kadın 185 hasta çalışmaya dahil edildi. Ortalama yaş 12.6 (dağııım 3-56) idi. Toplam 64 hastada Actinomiçes varlığı gösterildi.

Sonuç: Actinomyces türleri tonsil dokusu florasında firsatçı enfeksiyona neden olan bakterilerdir. Tonsiller Aktinomikoz kolonizasyonu yetişkinlerde ve büyük çocuklarda daha yaygindır.

Anahtar kelimeler: Tonsillektomi, Histopatoloji, Aktinomiçes.

Received: 31.012019 Accepted: 06.04.2019 Published (Online):29.10.2020

*Huseyin Gunizi, Departmant of Otolaryngology, Alanya alaaddin Keykubat University, Faculty of Medicine, Alanya, Turkey. Tel: +905059356648 e-mail: drgunizi@gmail.com

ORCID: 0000-0001-8653-0544

To cited: Gunizi OC, Gunizi H. Actinomyces in Tonsillectomy Materials. Acta Med. Alanya 2020;4(3): $260-263$. doi:10.30565/medalanya.791230 


\section{INTRODUCTION}

Ts onsillectomy is one of the most common surgeries in the pediatric age group. Tonsillectomy involves the surgical excision of palatine tonsils. Recurrent tonsillitis and obstructive sleep apnea caused by tonsillary hypertrophy are the most common indications for tonsillectomy. [1,2]

Actinomyces species are Gram-positive, nonspore-forming facultative anaerobic bacteria that cause infection in the cervicofacial, abdominopelvic, and pulmonothoracic regions. [3] Actinomycosis is a disease characterized by abscess formation, ranging from subacute to chronic infection. The term Actinomyces colonization defines colonization in tissues and does not constitute active disease. Actinomyces israelii and Actinomyces naeslundii are the most commonly isolated Actinomyces species, and all species except Actinomyces bovis are members of the natural flora of the human oral cavity.[46] These bacteria are found in gingival clefts and tonsillar crypts in the normal structure of oral flora, especially in periodontal pockets, dental plaques, decayed teeth, and the upper respiratory tract. They are known to cause infection via dental caries in the head and neck area, interventional dental treatments, maxillofacial traumas, and mucosal trauma in tonsils. Proteolytic enzymes produced by the bacterium cause infection to progress to deeper tissues.[7] Actinomycosis can be diagnosed by showing reproduction in culture or by observing sulfur granules in biopsy samples. $[8,9]$

In this study, the results of routine histopathologic examinations of patients who underwent tonsillectomy in our clinic were investigated for the presence of Actinomyces and the results were evaluated in view of the literature.

\section{MATERIALS AND METHODS}

In our study, the tonsillectomy materials of 185 patients who underwent tonsillectomy in our clinic between January 2016 and January 2019 due to recurrent tonsillitis and obstructive sleep apnea caused by tonsillary hypertrophy were retrospectively examined.
Patients' age, sex, vital signs, indications for tonsillectomy and preoperative data were recorded. The patients underwent tonsillectomy under general anesthesia. The surgically removed tonsil tissues were fixed with $10 \%$ formalin, embedded in paraffin wax and stained with hematoxylineosin. Preparations were evaluated under light microscopy, and histopathologic findings were recorded.

Our retrospective study was approved by Alaaddin Keykubat University İnstitutional Review Boards and Ethics Comittee (Ethics no:20-11).

Means and standard deviations of groups were calculated. Fisher's exact test was used to determine significant differences between nonparametric data from the groups. The data obtained in the study were evaluated statistically and the results with a $p$ value of $<0.05$ were evaluated significantly.

\section{RESULTS}

A total of 185 patients, 98 (53\%) males and 87 $(47 \%)$ females, who underwent tonsillectomy were included in the study. The mean age was 12.6 (range 3-56) years. Of the patients, 39 were aged under 6 years, 100 were aged between 6 and 18 years and 46 were older than 16 years. Of the patients, $104(56.2 \%)$ underwent tonsillectomy due to recurrent tonsillitis and $81(43.8 \%)$ due to chronic tonsillar hypertrophy and this issue is detailed in figure. (Figure 1). A total of 64 (34.6\%) patients showed the presence of Actinomyces. The presence of Actinomyces by gender is shown in the table. (Table 1). Allergic rhinitis was present in $16.8 \%(n=31)$ patients. We found a significantly increased incidence of Actinomyces in patients receiving treatment for allergic rhinitis $(67.7 \%)$.

Table 1. Actinomyces colonization and gender

\begin{tabular}{|l|l|l|l|}
\hline & \multicolumn{2}{|c|}{ Gender } & \multirow{2}{*}{ Total } \\
\cline { 1 - 3 } & male & female & \\
\hline Actinomyces - & 66 & 55 & 121 \\
\hline Actinomyces + & 32 & 32 & 64 \\
\hline Total & 98 & 87 & 185 \\
\hline
\end{tabular}




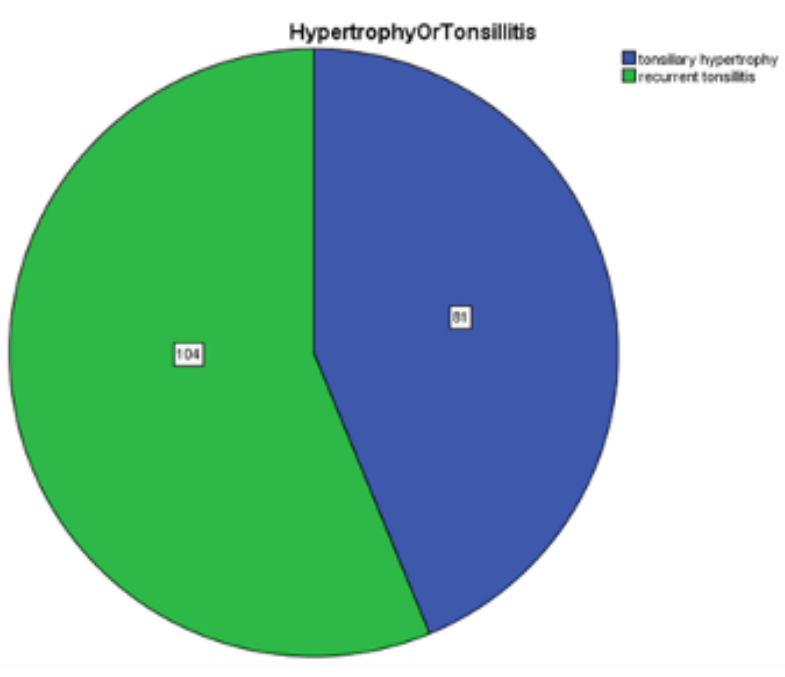

Figure 1: Number of Tonsillectomy due to recurrent tonsillitis or due to chronic tonsillary hypertrophy

\section{DISCUSSION}

The palatine tonsil is a large lymphoid tissue settled in a fossa formed by palatopharyngeal and palatoglossal muscles on both sides of the oropharynx. It reaches the largest volume at the ages of 5-6 years due to hyperplasia and atrophies at older ages. Absolute indications for tonsillectomy include tonsillar hyperplasia with obstructive sleep apnea, chronic tonsillitis, peritonsillar abscess, suspicion of malignant disease and hemorrhagic tonsillitis. Tonsillectomy is one of the frequent operations performed in the pediatric age group.

Actinomyces species were originally evaluated as fungi due to their branching fibrous structure, but were later shown to be Gram-positive bacteria.[10] Actinomyces israelii and Actinomyces naeslundii are the most commonly isolated Actinomyces species from humans, and these bacteria, which are normal flora elements, cannot overcome the robust mucosal barrier.[4-6] In the event that the mucosa is penetrated, it can cause infection by crossing the mucosal barrier.[11] Clinically, it may cause different pathologies such as fistula, abscess or pseudotumor. Typical microscopic findings include necrosis with yellowish sulfur granules and filamentous Gram-positive fungallike pathogens. Actinomyces develops a chronic granulomatous infection characterized by the formation of tiny clumps, called sulfur granules because of their yellow color. These formations of $0.1-1 \mathrm{~mm}$ in diameter, composed of an internal tangle of mycelial fragments and a rosette of peripheral clubs, are stabilized by a proteinpolysaccharide complex,.It is a homogeneous, eosinophilic saprophyte with structures extending towards the periphery in a radiative style in light microscopy. Besides clinical findings, microbiologic and histopathologic findings are important in diagnosis and the gold standard test for diagnosis is polymerase chain reaction. It is a penicillin-sensitive bacterium and penicillin is the first choice in treatment.[12]

Actinomyces species are detected in 1.8-37.0\% of tonsillectomy materials.[11-13] In our study, we found colonization in $64(34.6 \%)$ patients. Erkilic et al. found colonization in $8.2 \%$ of 1220 patients, and studies reporting a higher proportion are also available in the literature.[13] Toh et al. found colonization in $35.6 \%$ of 834 patients. [14] Antibiotic use before surgery is reported to affect the presence of Actinomyces in tonsillectomy materials. This major difference between the studies may be related to the different age groups in studies, different laboratories in which tests were performed and potentially the amount of antibiotics used before surgery.

Tonsillar Actinomyces are more frequent in adults, older children and men. Aydin reported that more Actinomyces were detected in adults in a study on 1820 patients.[15,16] Van Lierop and Melgarejo reported that this rate was higher in children aged over 5 years. $[6,16]$ In our study, we found the presence of Actinomyces in $39.1 \%$ of the adult age group, which was more than in the pediatric age group, in line with the literature. There are also studies that report that there are more male patients with Actinomyces, that there are more female patients with Actinomyces, or that female and male patients with Actinomyces are equal.[4$6,13,17]$ In our study, we found a higher rate of colonization in the female sex $(36.8 \%)$, but this result was not statistically significant.

Systemic diseases such as sickle cell anemia and thalassemia were noted to increase the presence of Actinomyces.[18] In our study, we found a significantly increased incidence of Actinomyces in patients receiving treatment for allergic rhinitis $(67.7 \%)$. However, we found no studies on this 
subject in the literature. The classic symptoms of the disorder are nasal congestion, nasal itch, rhinorrhea and sneezing. A thorough history, physical examination and allergen skin testing are important for establishing the diagnosis of allergic rhinitis. Second-generation oral antihistamines and intranasal corticosteroids are the mainstay of treatment. Intense postnasal influx in allergic rhinitis may aid colonization of this bacterium.

More Actinomyces species are found in patients with tonsillar hypertrophy than in patients with recurrent tonsillitis and it is thought that Actinomyces infection causes tonsil hypertrophy and increases apnea. It was explained that the presence of bacteria increases lymphoid hyperplasia and causes apnea due to tonsillar hypertrophy. Toh et al. found more Actinomyces in patients who underwent tonsillectomy due to sleep apnea than in patients who underwent tonsillectomy due to recurrent tonsillitis in their study.[14] The researchers thought that Actinomyces could play a role in the etiologic mechanism of tonsillar hypertrophy and reported that antibiotic treatment would reduce the symptoms of apnea and tonsil size in these patients.[18,19] In our study, the number of patients who underwent surgery for recurrent tonsillitis $(56.2 \%)$ was higher than for patients who underwent surgery for tonsillitis causing sleep apnea (43.8\%). We found more $(37.5 \%)$ Actinomyces in patients who underwent surgery for recurrent tonsillitis. However, we detected no significant link between Actinomyces colonization and tonsil hypertrophy and recurrent tonsillitis.

Conclusion: As a result, Actinomyces species are bacteria found in the tonsil tissue flora that cause opportunistic infection. Tonsillar Actinomyces colonization is more common in adults and in older children and is thought to contribute to obstructive apnea.

Financial disclosure: The authors declared that this study has received no financial support.

Conflict of interest: No conflict of interest was declared by the authors.

\section{REFERENCES}

1. Baugh RF, Archer SM, Mitchell RB et al. Clinical practice guideline: Tonsillectomy in children. Otolaryngol Head Neck Surg 2011; 144: 1-30. PMID: 21493257 DOI: 10.1177/0194599810389949

2. Smith MM, Peterson E, Yaremchuk KL. The role of tonsillectomy in adults with tonsillar hypertrophy and obstructive sleep apnea. Otolaryngol Head Neck Surg 2017; 157: 331 5 PMID: 28349770 DOI: 10.1177/0194599817698671

3. Hasan M, Kumar A. Actinomycosis and tonsillar disease. BMC Case Rep 2011. PMID: 22696708 DOI: $10.1136 / \mathrm{bcr} .01 .2011 .3750$

4. Gaffney R, Harrison M, Walsh M, Sweeney E, Cafferkey M. The incidence and role of actinomyces in recurrent acute tonsillitis. Clin Otolaryngol Allied Sci 1993 ;18:268 - 71. PMID: 8877183 DOI: 10.1111/j.1365-2273.1993.tb00845.x

5. Ozgursoy OB, Kemal O, Saatci MR, Tulunay O. Actinomycosis in the etiology of recurrent tonsillitis and obstructive tonsillar hypertrophy: answer from a histopathologic point of view. J Otolaryngol Head Neck Surg 2008; 37: 865-9. PMID: 19128718

6. Van Lierop AC, Prescott CA, Sinclair-Smith CC. An investigation of the significance of actinomycosis in tonsil disease. Int J Pediatr Otorhinolaryngol 2007; 71: 1883-8. PMID: 17919741 DOI: 10.1016/j.jporl.2007.08.021

7. Belmont M J, Behar P M, Wax M K. Atypical Presentation of Actinomycosis. Head Neck 1999;21:264-8. PMID: 10208670 DOI: 10.1002/(sici)1097-0347(199905)21:3<264:.:aidhed12>3.0.co; $2-y$

8. Mohanty S. Actinomycosis of faucial tonsil masquerading as oropharyngeal malignancy. Indian J Otolaryngol Head Neck Surg 2006;58:82 - 4. doi: 10.1007/BF02907750 PMCID: PMC3450608 PMID: 23120246

9. Yadav SP, Chanda R, Gathwala G, Yadav RK. Actinomycosis of tonsil masquerading as tumour in a 12-year old child. Int J Pediatr Otorhinolaryngol 2002;63:73-5. PMID: 11879933 DOI: 10.1016/s0165-5876(01)00647-4

10. Acevedo F, Baudrand R, Letelier LM, Gaete P. Actinomycosis: a great pretender. Case reports of unusual presentations and a review of the literature. Int $\mathrm{J}$ Infect Dis 2008; 12: 358-62 PMID: 18164641 DOI: 10.1016/j.jijid.2007.10.006

11. Choi MM, Baek JH, Lee JN, Park S, Lee WS. Clinical features of abdominopelvic actinomycosis: report of twenty cases and literature review. Yonsei Med J 2009: 50: 555-9. PMID: 19718405 PMCID: PMC2730619 DOI: 10.3349/ymj.2009.50.4.555

12. Garner JP, Macdonald M, Kumar PK. Abdominal actinomycosis. Int J Surg 2007; 5 : 441-8. PMID: 18078685 DOI: 10.1016/j.jjsu.2006.06.009

13. Riffat $F$, Walker P. Prevalence of tonsillar actinomyces in children undergoing tonsillectomy for sleep disordered breathing compared with recurrent tonsillitis. Int J Pediatr Otorhinolaryngol 2009; 73: 1111-3. PMID: 19447506 DOI: 10.1016/j.jporl.2009.04.015

14. Toh ST, Yuen HW, Goh YH. Actinomycetes colonization of tonsils: a comparative study between patients with and without recurrent tonsillitis. J laryngol Otol 2007; 121: 775-8. PMID: 17040606 DOI: 10.1017/S0022215106003185

15. Aydin A, Erkiliç S, Beyazit YA, Koçer NE, Ozer E, Kanlikama M. Relation between actinomycosis and histopathological and clinical features of the palatine tonsils: a comparative study between adults and pediatric patients. Rev Laryngol Otol Rhinol (Bord) 2005; 126: 95-8. PMID: 16180348

16. Melgarejo Moreno P, Hellin Meseguer, Marco Garrido A, Galindo Ortego X, Ruiz Macia $J A$, Hostalet F. A correlation between age and actinomyces in the adenotonsillar tissue of children. B-ENT2006; 2:95-7. PMID: 16910294

17. San T, Gürkan E, Erdoğan B, Özkanlı Ş. Does actinomyces have any role in tonsiller diseases in children? İstanbul Med J 2014;15:209-12 DOI: 10.5152/imj.2014.93798

18. Bhargava D, Bhusnurmath $B$, Sundaram KR et al. Tonsillar actinomycosis: a clinicopathological study. Acta Trop 2001; 80: 163-8.. https://doi.org/10.1016/S0001706X(01)00172-3

19. Pransky SM, Feldman JI, Kearns DB, Seid AB, Billman GF.Actinomycosis in obstructive tonsillar hypertrophy and recurrent tonsillitis. Arch Otolaryngol Head Neck Surg 1991; 117: 883-5 PMID: 1892620 DOI: 10.1001/archotol.1991.01870200077012 